\title{
Reducing Asthma Symptoms Through Swimming: A Case Study of 8-12-Year Old Children in Padang
}

\author{
Bafirman $\mathrm{Hb}^{1^{*}}$, Khairuddin ${ }^{2}$, Syahrastani ${ }^{3}$, Elsayuniarti ${ }^{4}$, and Asep Sujana Wahyuri ${ }^{5}$ \\ ${ }^{12345}$ Faculty of Sport Sciences, UniversitasNegeri Padang, Indonesia \\ **Corresponding author. Email: bafirman@gmail.com
}

\begin{abstract}
Objective: This study aims to examine whether swim training is effective in reducing asthma symptoms and can increase the Peak Expiratory Flow Rate (PEFR) and Vital Capacity (VC) in children who experience asthma symptoms. Sports training have been proven in improving lung function and asthma control in children, but better forms of training for asthmatics have not been determined up to recently. Swimming movements involve almost all the muscles of the body, increasing the ability of the respiratory muscles, so that it is effective reducing asthma symptoms. Methods: This qualitative and quantitative study with Research and Development approach was employed through several phases; (1) constructing information of asthma symptoms experienced by students, (2) developing of swim training programs, (3) limited trials and (4) swim training for children who experience asthma symptoms. This study involved 28 elementary school students aged 8-12 years in Padang taken by purposive sampling technique. Instruments used to collect data of asthma symptoms were experts (doctors)diagnosis, questionnaires, and interviews. Instrument used to collect data of PEF rate was a peak flow meter, and instrument used to collect data of VC was rotary spirometer. Data were analyzed using descriptive statistics, and t-test with $95 \%$ confidence interval. Results: Swimming activities(1) are effective in reducing asthma symptoms, (2) significantly increase PEF rate $(\mathrm{p}=0.00$ $<0.05)$ and, (3) significantly increase VC $(\mathrm{p}=0.00<0.05)$ in children who experience asthma complaints. Conclusions: This study shows that through swimming activities can reduce asthma symptoms for children aged 8-12 years in Padang.
\end{abstract}

Keywords: asthma symptoms, swimming, children

\section{INTRODUCTION}

Asthma symptoms in children potentially disrupt their growth and development. Respiratory tract inflammation causes narrowing of the respiratory tract lumen diameter due to smooth muscle contraction, blood pressure, bronchial tube inflammation, and thick mucus secretions. The impact of uncontrolled asthma can cause death for asthmatics because the breath can suddenly stop. Asthma symptoms cause adverse effects, namely a decrease in quality of life, a decrease of productivity, school absences, an increase of health costs, the risk of hospitalization and even death ${ }^{(1)}$.

Children who experience asthma symptoms encounter social and emotional suffering, less acceptable by their peers, because the low ability in various physical activities, limitations when doing physical activities, fatigue, lack of enthusiasm and, low levels of physical fitness. Asthma in children in USA is significantly associated with absence from school and loss of productivity, therefore, a better treatment program is needed to alleviate asthma syndromes in children ${ }^{(2)}$
Asthma symptoms are a world health problem that is not only infected in developed countries but also in developing countries ${ }^{(3)}$.Estimated number of people with asthma in worldwide are 325 million people, including the top 5 causes of death with prevalence rates that continue to increase especially in children (4).Asthma in Indonesia is included into the top 10 causes of morbidity and death, with the number of sufferers are 12,500,000 people ${ }^{(5)}$. Among 250 million people in Indonesia, $10 \%$ of them are suffering from asthma, it is feared that people with asthma will increase in children or those who are still in elementary school level ${ }^{(6)}$.

Risk factors of asthma in elementary school students in Padang based on the modified International Study of Asthma and Childhood (ISAAC) questionnaire found that the prevalence of asthma in elementary school students aged 6-7 years was $8 \%{ }^{(7)}$. The annual report of the Health Office of Padang from 2009 to 2011 showed that the occurrences of asthma were increased from $13.3 \%$ in 2009 to $15.4 \%$ in 2010 and $15.4 \%$ in $2011^{(8)}$. 
In children who experience asthma symptoms, physical and psychological changes can occur. Physical changes that occur due to recurrent asthma are barrelshaped chest, shoulder heightened, horizontal zygomatic bone, circle around the eyes, nose narrowed and upper teeth protruding ${ }^{(9)}$.Clinical symptoms that occur in children with asthma were dry cough, short of breath, wheezing (audible), fatigue and talking with short, broken and gasping phrases, insomnia, rapid heartbeat ${ }^{(10)}$. Changes that occur psychologically, such as feeling insecure, helpless, hopeless, confined or unable to move freely, cause children to feel loss of selfesteem.

Controlled asthma symptoms can be cured, but if it is uncontrolled, it will disrupt the quality of life and cause loss of school time ${ }^{(11)}$.Asthma can be caused by several factors, namely genetic factors and trigger factors. Genetic factors are trace in someone who is characterized by the presence of certain genes from someone with asthma. The gene is obtained because it was inherited. While trigger factors can be classified as trigger factors from outside and inside the body ${ }^{(12,13)}$.

"Sports Health Programs improve health and society level"(14). Sports activities, carried out correctly and at the right time, regularly, and measurably, are one of the efforts to improve the quality of the body organs functions so that the level of health and quality of life are increased ${ }^{(15)}$. Sports training has been proven in various studies to improve lung function and asthma control in children, a better form of training for asthmatics has not been determined to date ${ }^{(16)}$.Patients with asthma symptoms, when they train regularly, can improve the ability of body organs function such as cardiovascular fitness and pulmonary fentilation and strengthen the respiratory muscles ${ }^{(17)}$

One of the most popular and favored sports activities for anyone, especially by children, is swimming. All movements when swimming involve almost all the muscles of the body, increasing the ability of the respiratory muscles, so that it can be useful in resolving asthma symptoms. Swimming is often recommended as a form of physical activity for children who experience asthma symptoms. Swim training is more influential than other forms of training, because the air is moist and warm, hydrostatic pressure on the thoracic wall ${ }^{(18)}$.Physical training through swimming is an aerobic training. Regularly aerobic training improves management of asthma symptoms, lung functions, and mental health, which is a fairly safe sport and can be applied to all ages $\left({ }^{19)}\right.$.

Based on various problems that have been raised, the authors propose scientific work based on the research that has been done with the topic " Reducing Asthma Symptoms through Swimming: A Case Study of 8-12-Year Old Children in Padang " The purpose of this study is to examine whether swim training is effective in reducing asthma symptoms for children, which are evaluated from the asthma symptoms, Peak Expiratory Flow Rate (PEFR) and, Vital Capacity (VC). This scientific work is expected to be a study material for resolving asthma symptoms experienced by children, as an effort to improve the physical fitness of young people to build the good quality of human resources.

\section{METHODS}

This is a qualitative and quantitative research, with the design of Research and Development that is "cross-sectional and longitudinal".The implementation of the research was carried out in several phases, namely ; (1) Identifying asthma symptoms in children through the survey, (2) designing a swim training program, (3) trials, (4) validating the swim training program, and (5)applying swimtraining for children who experience asthma symptoms through the experimental method, for 10 weeks with a twice a week frequency of exercise.This study was conducted in an indoor swimming pool in Faculty of Sports Science Universitas Negeri Padang.

The population of this study is a group of elementary school students in Padang enrolled in 2017 2018 school year, aged 8 - 12 years. Purposive sampling was employed to get 28 students involved in this study. Instruments used to collect data of asthma symptoms were experts (doctors) diagnosis, questionnaires, and interviews. Instrument used to collect data of PEF rate was a peak flow meter, and instrument used to collect data of VC was rotary spirometer. Qualitative data analysis was done by using the Spradley model, domain analysis, focused observation and percentage. Quantitative data analysis was done by using descriptive statistics, hypothesis testing using the t-test, with a level of confidence $\alpha=0.05$. Before analyzing the data to answer the hypothesis, the normality test and the linearity test were first carried out.

\section{RESULTS}

\section{Asthma Symptoms}

After being diagnosed, children with asthma symptoms filled out questionnaires and were examined to find out the asthma symptoms they experienced. Children with asthma symptoms were characterized by several indicators such as; (1) Shortness of breath while resting, (2) repetitive wheezing, (3) chest painwhile resting, (4) coughing, (5) insomnia, (6) shortness of breath while training, (7) fast heartbeat rate while resting. Questions asked were answered withyes, sometimes and no. "Yes" meant that the child experienced what was being asked, "sometimes" meant 
that the symptoms were not always occurred, and "No" meant that the child did not experienced what was asked at all. It can be seen based on the following table.

Table 1. Condition of asthma symptoms reduction from pre-test to post-test

\begin{tabular}{|c|c|c|c|c|c|c|c|c|c|c|c|}
\hline \multirow[t]{2}{*}{ Symptoms } & \multicolumn{2}{|c|}{ Response } & \multicolumn{6}{|c|}{ Post Test } & \multicolumn{3}{|c|}{ Reducing of symptoms } \\
\hline & & & $\mathbf{y}$ & $\%$ & sometimes & $\%$ & $\mathbf{n}$ & $\%$ & & & \\
\hline \multirow{3}{*}{$\begin{array}{l}\text { 1. Shortness of } \\
\text { breath while } \\
\text { resting }\end{array}$} & \multirow{21}{*}{ 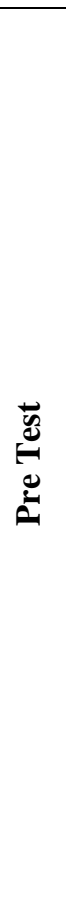 } & $\mathbf{y}$ & 0 & $0 \%$ & 3 & $11 \%$ & 0 & $0 \%$ & Reducing & 14 & $50 \%$ \\
\hline & & smt & 0 & $0 \%$ & 5 & $18 \%$ & 11 & $39 \%$ & Still & 14 & $50 \%$ \\
\hline & & $\mathbf{n}$ & 0 & $0 \%$ & 0 & $0 \%$ & 9 & $32 \%$ & Worse & 0 & 0 \\
\hline \multirow[t]{3}{*}{ 2.Wheezing } & & $\mathbf{y}$ & 0 & $0 \%$ & 3 & $11 \%$ & 0 & $0 \%$ & Reducing & 13 & $47 \%$ \\
\hline & & smt & 0 & $0 \%$ & 15 & $54 \%$ & 10 & $36 \%$ & Still & 15 & $54 \%$ \\
\hline & & $\mathbf{n}$ & 0 & $0 \%$ & 0 & $0 \%$ & 0 & $0 \%$ & Worse & 0 & 0 \\
\hline \multirow{3}{*}{$\begin{array}{l}\text { 3. Chest pain } \\
\text { while } \\
\text { resting }\end{array}$} & & $\mathbf{y}$ & 3 & $11 \%$ & 0 & $0 \%$ & 0 & $0 \%$ & Reducing & 5 & $18 \%$ \\
\hline & & smt & 0 & $0 \%$ & 14 & $50 \%$ & 5 & $18 \%$ & Still & 23 & $82 \%$ \\
\hline & & $\mathbf{n}$ & 0 & $0 \%$ & 0 & $0 \%$ & 6 & $21 \%$ & Worse & 0 & 0 \\
\hline \multirow[t]{3}{*}{ 4. Coughing } & & $\mathbf{y}$ & 4 & $14 \%$ & 2 & $7 \%$ & 0 & $0 \%$ & Reducing & 5 & $18 \%$ \\
\hline & & smt & 1 & $4 \%$ & 17 & $61 \%$ & 3 & $11 \%$ & Still & 21 & $75 \%$ \\
\hline & & $\mathbf{n}$ & 0 & $0 \%$ & 1 & $4 \%$ & 0 & $0 \%$ & Worse & 2 & $8 \%$ \\
\hline \multirow[t]{3}{*}{ 5. Insomnia } & & $\mathbf{y}$ & 2 & $7 \%$ & 0 & $0 \%$ & 0 & $0 \%$ & Reducing & 7 & $25 \%$ \\
\hline & & smt & 0 & $0 \%$ & 14 & $50 \%$ & 7 & $25 \%$ & Still & 21 & $75 \%$ \\
\hline & & n & 0 & $0 \%$ & 0 & $0 \%$ & 5 & $18 \%$ & Worse & 0 & 0 \\
\hline \multirow{3}{*}{$\begin{array}{l}\text { 6. Shortness of } \\
\text { breath while } \\
\text { training }\end{array}$} & & $\mathbf{y}$ & 0 & $0 \%$ & 5 & $18 \%$ & 0 & $0 \%$ & Reducing & 7 & $25 \%$ \\
\hline & & smt & 0 & $0 \%$ & 16 & $57 \%$ & 2 & $7 \%$ & Still & 21 & $75 \%$ \\
\hline & & $\mathbf{n}$ & 0 & $0 \%$ & 0 & $0 \%$ & 5 & $18 \%$ & Worse & 0 & 0 \\
\hline \multirow{3}{*}{$\begin{array}{l}\text { 7. Fast } \\
\text { heartbeat } \\
\text { rate while } \\
\text { resting }\end{array}$} & & $\mathbf{y}$ & 0 & $0 \%$ & 5 & $18 \%$ & 0 & $0 \%$ & Reducing & 9 & $32 \%$ \\
\hline & & smt & 0 & $0 \%$ & 14 & $50 \%$ & 4 & $14 \%$ & Still & 19 & $68 \%$ \\
\hline & & $\mathbf{n}$ & 0 & $0 \%$ & 0 & $0 \%$ & 5 & $18 \%$ & Worse & 0 & 0 \\
\hline
\end{tabular}

Descriptions: $\mathrm{y}=$ yes, $\mathrm{smt}=$ sometimes, $\mathrm{n}=\mathrm{no}$

Based on Table 1 above, it can be seen that the condition of asthma symptoms in children during pretest and post-tetst: (1) Shortness of breath while resting is reduced for 14 children (50\%) and still for 14 children (50\%). (2) Wheezing is reduced for 13 children $(47 \%)$ and still for 15 children $(54 \%)$. (3) Chest pain while resting is reduced for 5 children (18\%) and still for 23 children (82\%). (4) Coughing is reduced for 5 children $(18 \%)$ and still for 21 children (75\%). (5) Insomnia is reduced for 7 children $(25 \%)$ and still for 21 people (75\%). (6) Shortness of breath while training is reduced for 7 children (25\%) and still for 21 children
(75\%). (7) Fast heartbeat rate is reduced for 9 children $(32 \%)$ and still for 19 children $(68 \%)$.

\section{Increasing of Peak Expiratory Flow Rate (PEFR)}

After the data were obtained normal and linear, then the hypothesis is tested. The hypothesis proposed was "Swimming activities have a positive effect on increasing Peak Expiration Flow Rate (PEFR) of children with asthma. "Hypothesis tested results can be seen according to the following table.

Table 2. Descriptive and Comparison Results of Peak Expiratory Flow Rate between Tests

\begin{tabular}{|l|l|c|c|c|c|}
\hline \multirow{2}{*}{ Variable } & \multicolumn{3}{|c|}{ Descriptive } & \multirow{2}{*}{ t-test } \\
\cline { 2 - 5 } & \multicolumn{2}{|c|}{ Mean } & \multicolumn{2}{|c|}{ S.D. } & \\
\cline { 2 - 5 } & Pre-test & Post-test & Pre-test & Post-test & \\
\hline PEFR & 215.35, & 250 & 49.77 & 52.06 & $0,00<0,05$ \\
\hline
\end{tabular}

Based on descriptive data, the mean of PEFR in pre-test was 215.35, and post-test was 250. It indicated that there is an increasing tendency of PEFR after treatment for 34.65. After testing, the result of the PEFR between before and after the swim training treatment was 0.829 . With significance level of relationship was 
0,000 , it indicated a significant $<\alpha(0.05)$, strong and positive relationship. Therefore, swimming activities have a significant effect on increasing PEFR in children with asthma syndromes.

3. Increasing of Vital Capacity (VC)

Table 3. Descriptive and Comparison Results of Vital Capacity between Tests

\begin{tabular}{|l|c|c|c|c|c|}
\hline \multirow{3}{*}{ Variable } & \multicolumn{3}{|c|}{ Descriptive } & \multirow{2}{*}{ t-test } \\
\cline { 2 - 5 } & \multicolumn{3}{|c|}{ Mean } & Post-test & \\
\cline { 2 - 5 } & Pre-test & Post-test & Pre-test & 274.09 & $0,00<0,05$ \\
\hline VC & 1291.07 & 1424.28 & 385.74 & \\
\hline
\end{tabular}

Based on descriptive data, the mean of $\mathrm{VC}$ in pre-test was 1291.07, and post-test was 1424.28. It indicated that there is an increasing tendency of VC after treatment for 133.21. After testing, the result of the VC between before and after the swim training treatment was 0.753 . With significance level of relationship was 0,000 , it indicated a significant $<\alpha$ (0.05), strong and positive relationship. Therefore, swimming activities have a significant effect on increasing $\mathrm{VC}$ in children with asthma syndromes.

\section{DISCUSSION}

The research findings showed that; (1) swimming activities effectively reduced asthma symptomsin children, (2) swimming activities significantly improvedPEFR, and (3) swimming activities through swim training was proved by the reduction in asthma symptoms, increasing of PEFR, and $\mathrm{VC}$ in children with asthma symptoms.

\section{Swimming Activities Reduce Asthma Symptoms in Children}

Asthmatics need a solution to reduce asthma symptoms, beside treatment by doctors, there must be treatment beyond that serves as a therapy to help reducing asthma symptoms. Appropriate therapy help and reduce asthma symptoms, including complementary (non-pharmacological) therapy, one of which can be done through sports activities. Physical training is important in managing asthma, educating all teenagers about asthma simultaneously can reduce stigmatization and increase training involvement ${ }^{(20)}$. Increasing the involvement of physical activity in girls group can reduce asthma symptoms and the anxiety and depression they experienced ${ }^{(21)}$.

As stated earlier, one of the sports activities favored and loved by children is swimming. Swimming can evoke confidence and enthusiasm for life (22). Psychologically, anxiety / depression will affect the risk of asthma symptoms. Swimtraining programs are more beneficial for maximum breathing abilities compared to other sports training programs ${ }^{(16)}$.Swimming activities significantly improve VC. Reducing asthma symptoms
Based on the hypothesis proposed "Swimming activities have a positive effect on increasing Vital hypothesis tested can be seen in the following table. Capacity (VC) of children with asthma", the result of abdomen, and shoulders so that it can remedy the condition of asthma symptoms. Asthma symptoms are triggered by dry air, when one swims; breathing occurs near the surface of the water, steam makes the incoming air moist.

Swimming activities have a reciprocal relationship with respiration. Sport that is recommended for people with asthma is a light and simple sport, meaning that sport is adjusted to the ability of asthmatics ${ }^{(23)}$.Physical exercise is designed for asthmatics with the aim of improving physical fitness, neuromuscular coordination by increasing respiratory muscle strength and self-confidence ${ }^{(23)}$.

It is considered that by swimming, there is an increase in the ability of respiration, especially expiration ability in people with asthma. Swimming can be very beneficial for elderly people where there has been a decrease in lung capacity as a result of a decrease in lung function and a decrease in endurance of the respiratory muscles. Swimming can help children and adults with asthma. The results of the identification from several studies show that swimming can reduce the severity of asthma and Chronic Obstructive Pulmonary Disease (COPD) ${ }^{(24)}$.

Swimming can make the whole body work without the risk of joint injury, making it suitable for all agesso that the respiratory tract remains moistthat will not trigger asthma. The ideal exercise for people with asthma is swimming because they can breathe in humid and sometimes warm air. Being in a horizontal position when swimming can also free mucus settled at the base of the lungs ${ }^{(25)}$.

\section{Swimming Increases PEFR in Children with Asthma}

An evaluation of asthma level can be identified by monitoring the Peak Expiration Flow Rate(PEFR). PEFR examination is performed to assess the severity of airway obstruction by using the Peak Flow Meter. Peak flow meter is a device used to measure the amount of air flowing from the lungs of a patient in one breath, this tool can help measure the amount of air coming from the lungs, and also functions to control asthmatics. A 
Peak Flow Meteris relatively inexpensive and can be brought anywhere, so that the evaluation can not only be carried out in clinics, hospitals but can be done at patients'houseindependently. However, not many asthmatics understand and use them ${ }^{(26)}$.

The PEFR measured in liters / minute can give a warning to a decrease in lung function and describe the narrowing or obstruction of the airways ${ }^{(27)}$. Pressure due to forced expiration causes the diaphragm to move and open the area of the orifice more broadly. The PEFR value is influenced by several hundred milliliters of air starting from full inflation of the lungs and by the strength of the chest and abdomen muscles ${ }^{(28)}$. The most common pathological conditions affecting PEFRis disruption of the structure or function of the intrathoracic respiratory tract which increases air flow resistance. PEFR is also disrupted by extra-thoracic airway obstruction, a condition that limits chest wall movements or functions of the respiratory muscles and nervous system integrity. In the restrictive process due to interstitial lung disease, loss of lung volume is caused by an increase of elastic lung recoil ${ }^{(29)}$.

When the asthma symptoms occur, the intercostal muscles are frequently used than the rectus abdominis muscles, while the most important respiratory muscles are the diaphragm. Using the intercostal muscles in advance will cause weakness in the respiratory muscles so that an exercise to strengthen respiratory muscles is needed for asthmatics ${ }^{(30)}$.Swimming activities can improve quality of life and contribute to improving motor development ${ }^{(31)}$.Swimming is an effective non-pharmacological cure for children or adolescents with asthma ${ }^{(17)}$.

Based on findings of the study, swimming activities significantly increased the PEFR in children with asthma symptoms, as seen in the following graph:

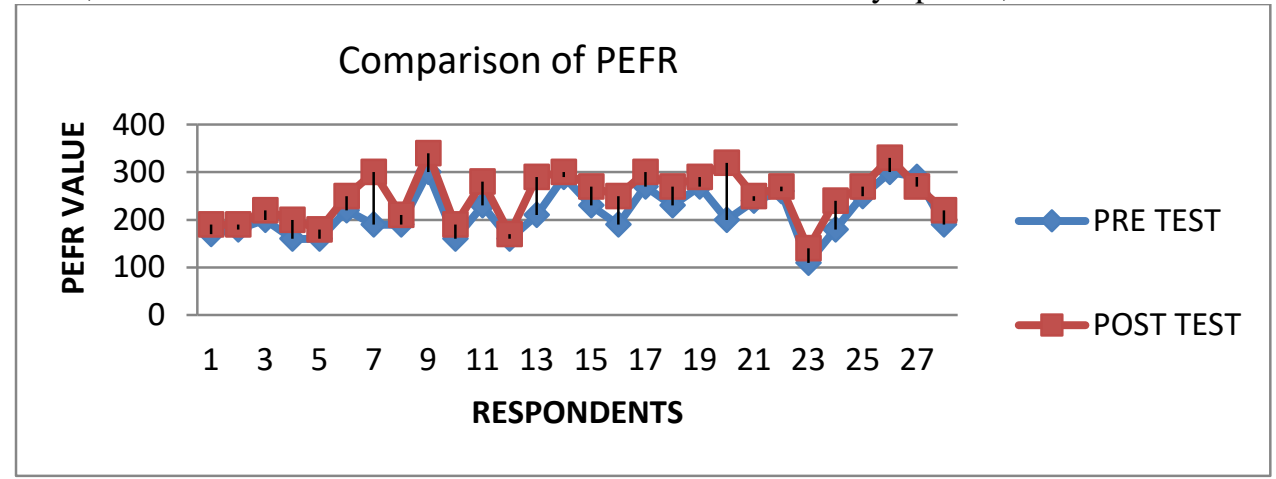

Graph 1. PEFR between Pre-Test and Post-Test

In accordance with the graph above, the PEFR of children with asthma between the pre-test and post-test on the average are increased. The maximum velocity value produced during expiration usually occurs at the first 150 milliseconds of forced expiratory maneuvers. Swimming involves almost all the main muscles of the body, especially the respiratory muscles. When patients with asthma symptoms do swim training regularly and continuously, it means that they indirectly have repeatedly trained the respiratory muscles, so that it will increase the ability and endurance of the respiratory muscles, which in turn will have an impact on increasing the value of PEFR.

\section{Swimming Increases VC in Children with Asthma}

Swimming regularly, with adequate intensity, brings the same physiological benefits to asthmatics, but asthmatics get additional value. This is due to the more efficient functioning of the respiratory system which includes: (1) Increasing maximal breathing capacity, (2) Reducing residual air volume (residual air) caused by reducing trapped air, and (3) More efficient pattern of pulmonary ventilation ${ }^{(32)}$.

Swimming activities increase the efficiency of the respiratory system so that diffusion capacity is greater. Changes in the respiratory system that occur due to swim training are; (1) increasing of minute volume as a result of increasing of normal respiratory volume (tidal volume) and breath frequency, (2) increasing of ventilation efficiency, i.e. the amount of air that is ventilated at the same oxygen consumption level will be lower, and (3) active skeletal muscle gets more oxygen from the respiratory muscles ${ }^{(33)}$.

Based on findings of the study, swimming activities significantly increased the $\mathrm{CV}$ in children with asthma symptoms, as seen in the following graph: 


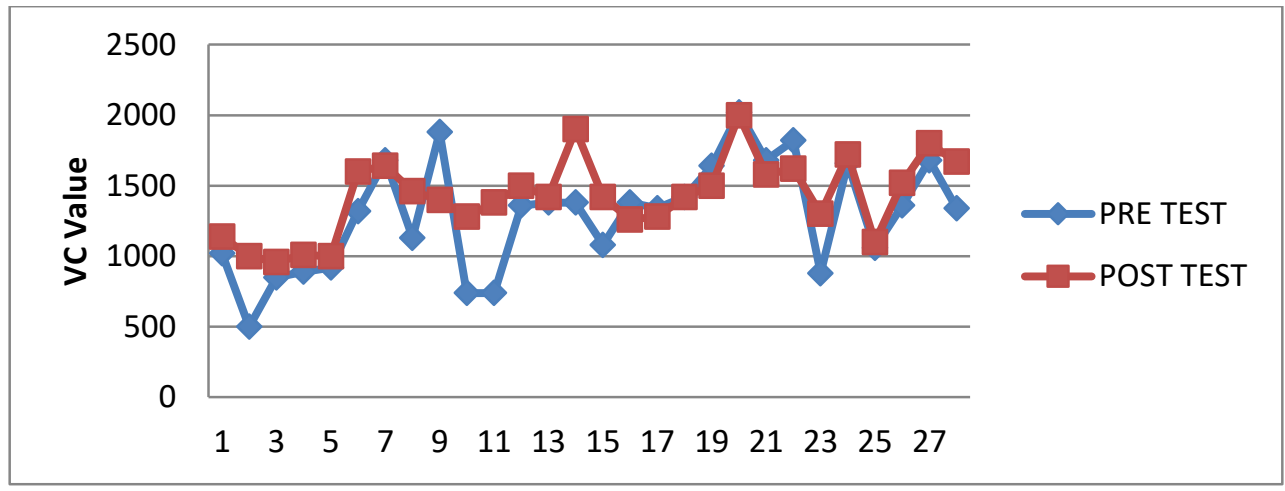

Graph 2. VC between Pre-Test and Post-Test

The value of vital capacity between before and after swim training activities in children with asthma symptoms shows that there is an improvement. This is in accordance with the theory that swimming can improve the flexibility of the chest cavity so that it can expand and deflate optimally, improve the flexibility and strength of the body cavity so that it optimizesabdominal breathing ${ }^{(34)}$. Swimming will strengthen the muscles. Improvement of muscle functions, especially the respiratory muscles, causes breathing to be more efficient while resting. Pulmonary ventilation between trained and non-trained people is relatively same, but trained people breathe slower and deeper. This causes the oxygen needed for muscle work in the ventilation process to decrease, so that with the same amount of oxygen, the trained muscle will work more effectively ${ }^{(35)}$.

Swimming has a significant effect on increasing the value of vital capacity. The effect of swimming on the improvement of lung volume has been clearly demonstrated to increase the strength of the lung muscles, increase the ability of the lungs to pump air, or directly accelerate lung growth as an adaptation response to training, especially in children ${ }^{(36)}$. Research on 15-year-olds kid who did swimming showed that he had higher pulmonary vital capacity values than children who did not do exercise. Swimming is considered to be an excellent exercise for maintaining health properly and also has a profound effect on lung function. Swimming regularly has a positive effect on the lungs by increasing lung capacity and thereby improving lung function. Lung function is generally determined by respiratory muscle strength, compliance with the chest cavity, airway resistance, and lung elasticity ${ }^{(37)}$.

Swimming activities are also considered as a means of recreation, held in quite large spaces equipped with various game facilities ${ }^{(38)}$. This is the right way to introduce swim training to children through playing. Swimming can increase endorphins in the brain, which is believed to give a comfort effect for someone and can eliminate stress. When floating in water, blood circulation to the brain can be flowed fluently which indeed is very beneficial for the health ${ }^{(39)}$.

Swimming activities not only avoid asthma attacks, it also can cure various respiratory problems such as snoring, out of breath and so on ${ }^{(40)}$.Through swimming can make children happy, it can improve the learning process, it makes children develop faster in the cognitive area, and physically. Parents participation and encouragement greatly determine the involvement and motivation of children to do swimming activities regularly and programmed ${ }^{(41)}$.Therefore, sports activities must be included as an important part of personalasthma management in clinical practice. Medium training can reduce asthma symptom scores by $0.66^{(42)}$

Swim training is well tolerated in children and adolescents with stable asthma. There is moderate evidence that it improves lung functions and improves cardiovascular fitness. No evidence showed that swimming causes adverse effects on asthma control. But is swimming better than other forms of activity? It cannot be determined from this review ${ }^{(43)}$.

\section{CONCLUSION}

Based on the findings and discussions that have been put forward, it can be concluded: (1) Swimming activities effectively reduce asthma symptoms in children, (2) Swimming activities significantly influence the improvement of PEFR in children with asthma symptoms, and (3) Swim training activities significantly affect the improvement of VC in children with asthma symptoms. Parents / guardians of students and teachers of Physical Education and Health give encouragement to their children who experience asthma symptoms to do swimming activities regularly with moderate intensity and excitement. 


\section{ACKNOWLEDGMENTS}

We thank to all children, and parents who allowed their children to participate in our research. Moreover, we would like to thank the Rector of UNP Padang who has given permission and assistance morally and materially to us in doing this research.

\section{REFERENCES}

[1] Prasetyo, B. 2010. Seputar Masalah Asma. Yogyakarta: Diva Press.

[2] Patrick Sullivan , PhD, Vahram G. Ghushchyan , $\mathrm{PhD}$, Prakash Navaratnam , PhD, at all. School absence and productivity outcomes associated with childhood asthma in the USA,Journal of Asthma Volume 55, 2018.

[3] Sundaru, H. 2007. Asma (Apa dan bagaimana pengobatanya). Jakarta: Balai Penerbit FK UI.

[4] GINA. 2015. Global Strategi For Asma Managemant and Prevention. Global Initiatif For Asma.

[5] Dinas Kesehatan Kota Padang. Laporan Tahunan Penyakit Asma 2009,2010,2011.

[6] WHO. 2006. Asthma. alveilebelin http://www.who.int/topics/asthma.

[7] Afdal, dkk. 2009. Faktor Risiko Asma Pada Murid Sekolah Dasar Usia 6-7 Tahun di Kota Padang. http://jurnal.fk.unand.ac.id.

[8] Dinas Kesehatan Provinsi Sumatera Barat. Profil Kesehatan Provinsi Sumatera Barat 2010.Padang :

Dinas Kesehatan Provinsi SUMBAR; 2011.

Yunus, F. (1997). Faal Parudan Olahraga. Jurnal

Respir Indonesia, Volume 17.

[9] Wong, D.L. 2003. Pedoman klinis keperawatan pediatrik. Terjemahan oleh Monica Ester. Edisi ke4. Jakarta: EGC.

[10] Supriyatno, B. 2005. Diagnosis dan penatalaksanaan terkini asma pada anak. MKI, vol 55 no 3, Maret 2005.

[11] Aryandani, R. 2010. Anak Sehat Bebas dari Asma. Yogyakarta: Golden Book.

[12] Pohan YH, Yunus F dan Wiyono WH. Asma dan Polusi Udara. Maj. Cermin Dunia Kedokteran [online] 2003;141:27-9.

[13] Undang-Undang Republik Indonesia Nomor 36 Tahun (2009) Tentang Kesehatan.

[14] Pedro Ángel Latorre-Román , PhD, Ana Vanesa Navarro-Martínez , PhD \&Felipe García-Pinillos. The effectiveness of an indoor intermittent training program for improving lung function, physical capacity, body composition and quality of life in children with asthma, Journal of Asthma, Volume 51, 2014.

[15] Chris Carew\&Des W Cox. 2017. Laps or lengths? The effects of different exercise programs on asthma control in children. Journal of Asthma Volume 54, 2017.

[16] Jeng-ShingW.,Wen-Ping $H$. The effects of a swimming intervention for children with asthma. Respirology. 14, 838-842 doi: $10.1111 /$ j.1440 . 1843.2009.01567.

[17] Katharina R Geiger, Nicholas Henschke. Swimming for children and adolescents with asthma . British Journal of Sports Medicine 49(12) February 2014.

[18] Kimberly M. Avallone , M.A. \&Alison C. McLeish. Asthma and Aerobic Exercise: A Review of the Empirical Literature, Journal of Asthma Volume 50, 2013.

[19] C. O. N. Winn, MSc(res), K. A. Mackintosh , PhD , W. T. B. Eddolls , BSc at.al. Perceptions of asthma and exercise in adolescents with and without asthma. Journal of Asthma Volume 55, 2018

[20] Dana Tiggelman , Monique OM van de Ven Onno CP van Schayck, at.al. Moderating effect of gender on the prospective relation of physical activity with psychosocial outcomes and asthma control in adolescents: a longitudinal study, Journal of Asthma, Volume, Volume 51, 2014.

[21] Jae Ho Chung\&Chang Hoon Han. Health related quality of life in relation to asthma - Data from a cross sectional stud, Journal of Asthma, Volume 55, 2018.

[22] Ram, F., S., F., Robinson, S., M., Black, P., N., Picot, J. 2005. Physical Training For Asthma. http://www. cochrane. org/reviews/en/ab001116.html.

[23] Ray AD, Pendergast DR, Lundgren CE. Respiratory muscle training improves swimming endurance at depth. Journal Undersea Hyperb Med. 2008 May-Jun;35(3):185-96.

[24] Fuhlbrigge A, Peden D, Apter AJ, BousheyHA,Camargo CA, Gern J et al. 2012. Asthma outcomes : Exacerbation. $J$ Allergy Immunol vol 129 hal 35-45.

[25] Persatuan Dokter Paru Indonesia. 2003. “Asma: Pedoman diagnosis dan Penatalaksanaan di Indonesia." Jakarta: PDPI. Sumber: http://www. klikpdpi.com/ konsensus/ asma.

[26] Mangunnegoro, Hadiarato, dkk. (2004). Asma Pedoman Diagnosis \&Penatalaksanaan Di Indonesia. Jakarta: Perhimpunan Dokter Paru Indonesia.

[27] Sheikh ,et al. 2000. Can Peak Expiratory Flow Predict Airflow Obstruction in Children With Asthma?.Pediatrics. Hal: 105:354-8.

[28] Pedersen L, Lund TK, Barnes PJ, Kharitonov SA, Backer V. Airway responsiveness and 
inflammation in adolescent elite swimmers. $J$ Allergy Clin Immunol 2008;122:322-327.

[29] Shaffer TH, Wolfson MR dan Bhutani VK. 2012. Respiratory Muscle FunctionAssesment And Training. United States Of America:Physical Therapy Journal of The American Physical Therapy Association.

[30] Elif Top.The Effect of Swimming Exercise on Motor Development Level in Adolescents with Intellectual Disabilities. American Journal of Sports Science and Medicine, 2015, Vol. 3, No. 5, 85-89 Available online at http://pubs.sciepub.com/ajssm/3/5/1 @ Science and Education Publishing, DOI:10.12691/ajssm-3-5-1.

[31] Yunani -, Dian Puspitasari, Erna Sulistiyawati. Perbedaan Kapasitas Vital Paru Sebelum Dan Sesudah Berenang Pada Wisatawan Di Kolam Renang Taman Rekreasi Kartini Rembang. Jurnal eperawatan Medikal Bedah, Persatuan Perawat Nasional Indonesia ISSN2338- Vol1, No.2,2013.

[32] I Made Kusuma Wijaya, Aktivitas Fisik (Olahraga) Pada Penderita Asma.Proceedings Seminar Nasional FMIPA UNDIKSHA V Tahun 2015

[33] Rogayah, R. Pengaruh Penyuluhan dan senam Indonesia terhadap pengetahuan, sikap, perilaku dan gejala klinik pasien asma. Jurnal Respir Indonesia Paru,1999/ 116-124.

[34] Smith, D \& Brawn, K. 2007. Terapi Pernafasan untuk Penderita Asma. Jakarta : Prestasi Pustakaraya.

[35] Guyton \& Hall. 2008. Fisiologi Manusia dan Mekanisme Penyakit. Edisi ke-7. Jakarta: EGC.

[36] P Kippelen, C Caillaud, E Robert, at.al.Effect of endurance training on lung function: J Sports Med 2005; 39:617-621. doi: 10.1136/bjsm.2004.014464.
[37] R. P. Pareek, Pintu Modak. The Effect of Swimming on Pulmonary Function in Healthy Student Population, International Educational EJournal, \{Quarterly\}, ISSN 2277-2456, VolumeII, Issue-IV, Oct-Nov-Dec 2013.

[38] Gaunt T, Maffulli, N. Soothing suffering swimmers: a systematic review of the epidemiology, diagnosis, treatment and rehabilitation of musculoskeletal injuries in competitive swimmers. British Medical Bulletin, Volume 103, Issue 1, 1 September 2012, Pages 4588, https://doi.org/10.1093/bmb/ldr039.

[39] McGovern. The Effects of Exercise on the Brain.2005. Biology 202.Serendip.

[40] Matsumoto, H Araki, K Tsuda, at al. EVects of swimming training on aerobic capacity and exercise induced bronchoconstriction in children with bronchial asthma. Journal of Exercise Science and Fitness. Original articles. Thorax 1999;54:196-201.

[41] Jennifer R. Pharr, 2014. Parental Factors That Influence Swimming in Children and Adolescents. International. Journal of Aquatic Research and Education, 2014, 8, 368-381 http://dx.doi.org/10.1123/ijare.2014-0041

[42] Sirpa A. M. Heikkinen , MD, Elina M. S Mäkikyrö , at.al. Effects of regular exercise on asthma control in young adults, Journal of Asthma , Volume 55, 2018

[43] Katharina R. Geiger, Nicholas Henschke. Swimming for children and adolescents with asthma. British Journal of Sports Medicine, published on February 18, 2014 as 10.1136/bjsports-2013-093397. Volume 49, Issue 12. http://dx.doi.org/10.1136/bjsports-2013 093397 